\title{
Pengujian Kebolehpercayaan Instrumen Sikap Dan Persepsi Terhadap Akademik Dan Sahsiah: Pengaplikasian Model Rasch
}

\author{
Mohamad Affi Yusri Mohamad Zaini", Nooraini Othman \\ Sekolah Perdana Polisi Sains, Teknologi dan Inovasi (UTM Perdana School), Universiti Teknologi Malaysia Kuala Lumpur, Jalan Sultan Yahya Petra, 54100 \\ Kuala Lumpur \\ *Corresponding author: affyusry@yahoo.com
}

\begin{abstract}
This study aims to highlight the process of reliability testing for the instrument development in measuring the attitude and perception of adolescent toward academic and personality. The testing process is implemented in the form of quantitative research where data collection is made by using questionnaires. The instrument was developed by the researcher under the supervision of experts in the field of psychology. A pilot study of 30 samples was carried out to test the reliability of the instrument. Rasch model was used to test the reliability of the measurement for each item. Reliability value of .95 for person and .91 for item indicates that the instrument has a high degree of reliability. After dropping the four items misfit, dimensionality testing found that the variance explained by measure for each construct is more than 40 percent. This result shows that the items are highly reliable and suitable for the real data collection.
\end{abstract}

Keywords: Attitude, perception, instrument development, reliability test, rasch model

\begin{abstract}
Abstrak
Kajian ini bertujuan untuk menyoroti proses pengujian kebolehpercayaan bagi pembinaan instrument untuk mengukur sikap dan persepsi remaja terhadap akademik dan sahsiah. Proses pengujian ini dilaksanakan dalam bentuk kajian kuantitatif di mana pengumpulan data dibuat dengan menggunakan borang soal selidik. Instrumen kajian ini telah dibina sendiri oleh penyelidik di bawah seliaan pakar dalam bidang psikologi. Kajian rintis ke atas 30 orang sampel telah dijalankan untuk membolehkan ujian kebolehpercayaan bagi instrumen dijalankan. Kaedah Model Rasch telah digunakan bagi menguji tahap kebolehpercayaan pengukuran bagi setiap item. Nilai kebolehpercayaan .95 bagi individu dan .91 bagi item menunjukkan instrumen mempunyai tahap kebolehpercayaan yang tinggi. Setelah menggugurkan empat item misfit, pengujian dimensionality mendapati nilai variance explained by measure bagi setiap konstrak melebihi 40 peratus. Ini menunjukkan instrumen mempunyai item yang mempunyai kebolehpercayaan yang tinggi dan sesuai digunakan bagi pengumpulan data sebenar.
\end{abstract}

Kata Kunci: Sikap, persepsi, pembinaan instrumen, ujian kebolehpercayaan, rasch model

(C) 2016 Penerbit UTM Press. All rights reserved

\subsection{PENDAHULUAN}

Selaku makhluk yang bersifat kompleks, manusia akan sentiasa berhadapan dengan pelbagai jenis masalah dalam kehidupan. Antara masalah-masalah yang dihadapi adalah seperti masalah kendiri, masalah keluarga, peningkatan kos hidup, kesesakan jalan raya, kesibukan di tempat kerja, masalah komuniti setempat dan banyak lagi. Malah, manusia juga turut terdedah kepada isu-isu yang lebih besar dan bersifat global seperti masalah politik dalam dan luar negara, masalah ekonomi, masalah sosial, peningkatan kadar jenayah dan lain-lain lagi. Bagi memastikan kehidupan di dunia berjalan lancar, manusia perlu menyelesaikan masalah-masalah yang dihadapi (Mohd Aziz Shah dan Nazariah, 2008) dan perlu berinteraksi dengan isu-isu yang berlaku di sekeliling mereka secara berhemah dan bijaksana. Manusia perlu bersikap ambil tahu terhadap apa yang berlaku di persekitaran dan sekeliling mereka kerana mereka merupakan sebahagian daripada persekitaran kehidupan. Persoalan-persoalan akan timbul menyelubungi minda mereka hasil daripada interaksi dengan alam sekeliling. Bagi berhadapan dengan situasi ini, manusia perlu merangsang aktiviti minda mereka agar mewujudkan sesuatu pendapat, pandangan atau persepsi yang akhirnya menatijahkan sikap terhadap isu tersebut (Rozmi Ismail, 2011). Sebagai contoh, persoalan seperti apakah pandangan mengenai sistem politik dan kebebasan bersuara yang wujud di negara Malaysia? Apakah wujud peluang pekerjaan yang mencukupi bagi graduan-graduan yang keluar daripada universiti? Mengapakah remaja kita kini jauh terseleweng daripada norma dan dan tatasusila budaya masyarakat Timur? Kesemua persoalan ini membuktikan bahawa manusia sedang membincangkan sesuatu isu berdasarkan pemikiran yang wujud dalam minda mereka.Kemampuan menjalankan aktiviti berfikir merupakan gagasan penting yang dimiliki oleh manusia. Pemikiran manusia beroperasi melalui aktiviti minda yang berpusat di bahagian otak. Pemikiran manusia beroperasi melalui aktiviti minda yang berpusat di bahagian otak manusia (Mohd Azhar Abdul Hamid, 2007). Kemampuan menjalankan aktiviti ini membolehkan manusia 
menjalankan peranan mereka di dunia. Perkara ini menjadikan manusia berbeza dengan makhluk yang lain. Dengan kemampuan untuk menjalankan aktiviti berfikir ini, manusia mampu untuk menterjemahkan apa yang dilihat di sekeliling dalam bentuk persepsi, perkataan, perasaan, perilaku dan perbuatan ketika berinteraksi dengan persekitaran dan dunia sosialnya. Persepsi, perasaan, perilaku dan perbuatan ini merupakan menifestasi atau cerminan daripada pemikiran mereka yang juga dikenali sebagai sikap (Rozmi Ismail, 2011. Oleh itu, kajian ini dijalankan bagi membincangkan aspek sikap dan persepsi yang dihadapi oleh remaja dalam berhadapan dengan kehidupan mereka. Pemerhatian terhadap sikap remaja adalah melalui tingkah laku harian dalam aspek akademik dan sahsiah manakala persepsi pula adalah melalui pandangan atau anggapan.

Tujuan kajian ini dijalankan adalah bagi menyoroti proses pengujian kebolehpercayaan bagi instrumen yang telah dibangunkan dengan menggunakan kaedah model Rasch. The one-parameter Item Response Theory model atau model Rasch adalah kaedah analisis yang berpandukan model matematik yang semakin digunakan bagi pengesahan instrumen serta ujian kebolehpercayaan tahap pengukuran bagi setiap item. adalah model psikometrik untuk menganalisis data berkategori, seperti jawapan kepada soalan-soalan pada penilaian atau soal selidik. Selain penyelidikan dalam bidang psikometrik dan pendidikan, model Rasch juga bersesuaian digunakan dalam bidang-bidang yang lain (Wright, 1977) seperti profesion kesihatan (Bezruczko, 2005), penyelidikan pasaran ekonomi (Bechtel, 1985) dan lain-lain. Dalam model Rasch, kebarangkalian jawapan yang dinyatakan dimodelkan sebagai satu fungsi orang dan item parameter. Sebagai contoh, dalam ujian pendidikan, parameter item mewakili kesukaran item manakala parameter orang mewakili keupayaan atau tahap pencapaian orang-orang yang dinilai. Semakin tinggi kemampuan seseorang berbanding dengan kesukaran item, semakin tinggi kebarangkalian jawapan yang betul dalam item tersebut. Apabila tahap sifat sesorang adalah sama dengan tahap kesukaran item, berkebarangkalian 0.5 tindak balas yang diukur adalah betul berdasarkan model Rasch itu.

Walaupun model Rasch masih baru dan agak jarang digunakan bagi kajian-kajian dalam negara, terdapat beberapa kajian yang telah menggunakan kaedah model Rasch bagi menguji kebolehpercayaan instrumen. Antaranya seperti kajian yang dijalankan oleh Faizah Abd. Ghani et. al (2015), yang telah membangunkan satu modul berdasarkan perspektif Islam bertajuk 'Sayangku' (MyLove) sebagai alat untuk membantu remaja yang terlibat dalam aktiviti seksual sebelum kahwin. Pengujian kebolehpercayaan kajian ini dilakukan menggunakan kaedah model Rasch. Dari analisis Rasch telah mencatatkan nilai kebolehpercayaan .95 bagi individu dan . 80 bagi item. Selain itu, pengujian dimensionality mendapati nilai variance explained by measure telah mencatatkan lebih daripada $40 \%$. Ujian sebenar telah menunjukkan keputusan yang lebih baik daripada ujian pra dan membuktikan keberkesanan modul.

Selain itu, Adibah Abd Latif (2013), juga telah menggunakan kaedah model Rasch bagi menguji instrumen bagi kajiannya yang bertajuk Pembangunan Instrumen Penilaian Akhlak Pelajar di Institusi Pengajian Tinggi Awam. Kajian ini dijalankan bagi membangunankan satu instrumen penilaian akhlak pelajar Islam di universiti tempatan. Pengujian kebolehpercayaan kajian ini juga dilakukan menggunakan kaedah model Rasch. Dari analisis Rasch telah mencatatkan nilai kebolehpercayaan .96 bagi individu dan .93 bagi item. Selain itu, pengujian dimensionality mendapati nilai variance explained by measure telah mencatatkan lebih daripada $40 \%$.

\subsection{KONSEP ASAS KAJIAN}

Penjelasan mengenai konsep asas bagi kajian adalah penting bagi pembangunan sesuatu instrumen. Kajian ini meliputi tiga konsep asas yang perlu difahami iatu sikap, persepsi serta aspek akademik dan sahsiah. Perbincangan akan ditumpukan berdasarkan konteks dan keperluan kajian sahaja. Selain itu, perbincangan mengenai proses pembentukan dan hubungan antara ketiga-tiga konsep ini turut dibincangkan.

\section{Konsep Sikap}

Sikap adalah satu konsep terpenting dalam cabang psikologi sosial. Beliau menegaskan bahawa sikap yang dipaparkan oleh manusia ini adalah punca kepada pelbagai bentuk tingkah laku sosial yang kita semua pernah alami iaitu seperti tingkah laku prejudis, diskriminasi, prososial dan lain-lain. Menurut Petty dan Cacioppo (1986), sikap adalah sebagai satu penilaian am yang kekal mengenai manusia, objek atau isu-isu tertentu. Sikap merupakan sesuatu yang kekal kerana sikap tidak berubah mengikut masa. Menurut Asmawati Desa (2004), sikap merupakan perasaan positif atau negatif seseorang individu terhadap sesuatu. Perasaan inilah yang akan menentukan pelbagai bentuk gelagat sosial yang kita paparkan terhadap individu-individu tertentu atau sesuatu kumpulan. Tingkah laku tersebut adalah seperti gelagat prejudis, diskriminasi, prososial dan lain-lain. Menurut Wan Suryati Wan Ahmad (2008), sikap adalah satu proses mental yang bersifat fikiran, perasaan atau tanggapan terhadap sesuatu objek atau situasi tertentu.

Sikap secara umumnya dilihat sebagai sesuatu yang berbentuk penilaian sosial dan ia boleh berada pada seseorang dan boleh diukur (Rozmi ismail, 2011). Sikap terdiri daripada beberapa elemen. Elemen-elemen yang dimaksudkan ialah afektif, konasi dan kognisi. Teori ini dikenali sebagai model ABC mengenai sikap [8]. Menurut Breckler, elemen afektif adalah emosi atau perasaan manusia sama ada positif atau negatif terhadap sesuatu perkara. Elemen konasi atau tingkah laku pula melibatkan niat manusia untuk melakukan sesuatu ataupun memaparkan sesuatu tingkah laku secara langsung selaras dengan sikapnya. Elemen kognisi pula memerihalkan cara manusia berfikir dan menginterpretasikan sesuatu rangsangan bagi membentuk sikap selaras dengan emosi dan tingkah laku yang sedia ada. Oleh itu, sesuatu sikap akan mempunyai komposisi emosi, tingkah laku dan kognisi dan ketiga-tiga ini berinteraksi antara satu dengan yang lain (Ciccarelli, 2006).

\section{Konsep Persepsi}

Persepsi difahami dengan tanggapan bahawa dua orang melihat satu rangsangan yang sama akan menghasilkan kefahaman yang berbeza. Sebagai contoh, apabila dua orang melihat awan orang pertama mungkin fikir awan itu berbentuk seperti kuda, manakala orang yang kedua mungkin fikir ia berbentuk seperti lembu (Ciccarelli, 2006). Sunaryo (2004) telah meletakkan syarat-syarat untuk berlakunya proses persepsi iaitu; 1) wujudnya objek, 2) wujudnya perhatian daripada pelaku (perceiver) yang merupakan langkah pertama sebagai suatu langkah persiapan dalam mengadakan persepsi, 3) wujudnya pancaindera (reseptor) iaitu alat perantaraan bagi menerima stimulus (rangsangan), 4) wujudnya proses di mana saraf sensori yang menghantar stimulus (rangsangan) ke bahagian minda, diproses seterusnya mewujudkan respon. 
Menurut Atkinson dan Hilgard (1983), persepsi berbeza dengan kederiaan. Persepsi ialah suatu fenomena perkaitan antara rangsangan yang diterima dengan pengalaman sedia ada. Persepsi bersifat lebih kompleks berbanding dengan kederiaan di mana fenomena persepsi adalah tertakluk kepada proses-proses tahap tinggi.

Persepsi merupakan proses mengetahui objek-objek dan peristiwa yang objektif melalui kederiaan. Sugihartono (2007) menyatakan bahawa persepsi adalah kemampuan otak dalam menterjemahkan stimulus (rangsangan) atau proses untuk menterjemahkan stimulus (rangsangan) yang masuk ke dalam pancaindera manusia. Menurut Miftah Thoha (2003), terdapat dua faktor yang boleh mempengaruhi persepsi seseorang iaitu; 1) Faktor dalaman (internal): perasaan, sikap dan keperibadian individu, prasangka, keinginan atau harapan, perhatian (fokus), proses belajar, keadaan fizikal, gangguan kejiwaan, nilai, minat serta motivasi, 2) Faktor luaran (external): latar belakang keluarga, informasi yang diperoleh, pengetahuan dan keadaan sekitar, intensiti, ukuran, keberlawanan, pengulangan gerak, hal-hal baru dan kebiasaan atau ketidakasingan suatu objek.

\section{Aspek Akademik dan Syahsiah (Pencapaian)}

Pencapaian merupakan tahap kemampuan seseorang dalam aspek tertentu. Pencapaian dapat didefinisikan sebagai 1) tahap kemampuan atau penguasaan prestasi dalam kemahiran tertentu atau kumpulan pengetahuan, 2) kemajuan di sekolah. Smith \& Hudgins (1964) mengatakan bahawa pencapaian adalah usaha untuk melakukan sesuatu yang terbaik, untuk berjaya, untuk melaksanakan tugas-tugas yang memerlukan kemahiran dan usaha yang diiktiraf oleh pihak berkepentingan. Definisi yang umum telah diberikan oleh Yelon et. al (1977) dengan menyatakan bahawa pencapaian sebagai kejayaan bagi seseorang individu. Di samping itu, De Cecco \& Crawford (1977) menyatakan bahawa pencapaian adalah jangkaan tahap ke arah kesempurnaan dalam menguasai prestasi yang bersifat sukar dan mencabar. Daripada definisi-definisi yang telah diberikan, dapat disimpulkan bahawa pencapaian merupakan hasil atau persembahan seseorang individu bagi melihat prestasinya dalam bidang tertentu.

Berdasarkan konteks kajian, sikap dan persepsi remaja yang ingin dilihat menerusi pencapaian adalah dari sudut akademik dan sahsiah. Pengkaji berpendapat bahawa aspek akademik dan sahsiah merupakan perkara yang sesuai untuk dilihat dalam konteks kehidupan seorang remaja. Pencapaian positif dalam aspek akademik yang dimaksudkan mempunyai kaitan langsung dengan proses pembelajaran di institusi pengajian. Pembelajaran yang dimaksudkan dalam konteks kajian adalah pembelajaran secara formal yang melibatkan pengajaran ilmu pengetahuan sama ada di sekolah atau di institusi pengajian tinggi. Pencapaian akademik dalam konteks ini tidak mengguna pakai pemahaman pencapaian akademik sebagai pengetahuan yang diperoleh atau kemahiran yang dibangunkan dalam mata pelajaran sekolah, biasanya ditetapkan oleh skor ujian atau dengan tanda yang diberikan oleh guru atau kedua-duanya.

Aspek kedua yang ingin dilihat dalam kalangan anak-anak muda Kampong Bharu ialah sahsiah. Merujuk kepada Kamus Dewan Edisi Keempat (2005), sahsiah bermaksud keperibadian, peribadi: yg utama ialah menuntut ilmu dan melengkapkan proses pembinaan peribadi atau sebagai insan yang terpuji. Sahsiah juga dikenali sebagai keperibadian dan personaliti. Wan Azmi menyatakan bahawa sahsiah merupakan penentu kepada tingkah laku dalam diri individu daripada alam sekeliling (Wan Azmi Ramli, 1986). Sahsiah merangkumi makna akhlak, moral dan etika iaitu sifat dan perlakuan yang baik, halus dan benar dan patut dipunyai oleh seseorang yang memberikan kebaikan kepada dirinya dan orang lain. Ia merupakan suatu keadaan atau sifat yang ada di dalam diri atau jiwa manusia yang telah tetap, sehingga dengan mudah melahirkan perlakuan atau perilaku yang baik atau buruk tanpa difikir atau dirancang terlebih dahulu (Muhd Sulaiman Yasin, 1992). Oleh itu, dapat disimpulkan bahawa sahsiah sebagai sikap atau sifat yang telah sebati dalam diri seseorang.

Aspek akademik yang ingin dilihat adalah menerusi pencapaian kemajuan pelajar terhadap matlamat dan objektif kurikulum yang mana berorientasikan usaha dan komitmen sebagai seorang pelajar Garisson et. al (1964). Berdasarkan konteks kajian, persepsi yang ingin diteliti dalam aspek akademik adalah persepsi remaja terhadap kepentingan pelajaran dalam kehidupan, manakala sikap yang diteliti dalam aspek ini adalah sikap yang berkaitan dengan akademik seperti sikap seorang pelajar terhadap pembelajaran dan sikap tolong menolong dalam pembelajaran. Manakala, aspek sahsiah ini akan ditumpukan kepada menilai tanggungjawab remaja selaku anak kepada ibu bapa dan sebagai ahli warga sosial. Hal ini kerana tanggungjawab terhadap ibu bapa dan warga sosial amat bertepatan dengan kehidupan mereka yang masih bergantung hidup dengan ibu bapa dan tinggal di kawasan kejiranan suasana kampung. Berdasarkan konteks kajian, persepsi yang ingin diteliti dalam aspek ini adalah persepsi remaja terhadap sahsiah baik manakala sikap yang diteliti dalam aspek ini ialah sikap yang berkaitan dengan remaja cemerlang seperti sikap hormat ibu bapa, bertanggungjawab dan kejujuran.

\subsection{METODOLOGI}

Melalui proses tinjauan, data-data dikumpul dengan menggunakan instrumen yang ditadbirkan oleh pengkaji di tempat kajian. Kaedah ini merupakan kaedah yang berkesan bagi mendapat maklumat daripada responden selain membuat pemerhatian tingkah laku mereka. Pendekatan yang digunakan bagi mengumpulkan data bagi kajian ini adalah melalui borang soal selidik. Borang soal selidik merupakan borang yang berisi set soalan serta ruangan jawapan yang teratur diedarkan kepada respondan untuk mendapatkan sesuatu maklumat mengenai objektif penyelidikan melalui responden. Hasil daripada pengumpulan data, keputusan kajian ini akan dipersembahkan dalam bentuk analisis statistik deskriptif.

\section{Penyediaan Instrumen}

Pengkaji telah membina satu instrumen dalam bentuk borang soal selidik. Bahasa Malaysia digunakan sebagai bahasa perantara bagi mendapatkan maklumat dan data melalui borang tersebut. Penyelidik telah membina kerangka konstruk dan sub konstruk bagi instrumen yang dipandu oleh pakar dalam bidang psikologi. Selepas itu, penyelidik telah menjalankan proses penentuan dan penyusunan item bagi setiap sub konstruk yang telah dibina. Terdapat 2 konstruk utama dalam instrumen ini iaitu; 1) persepsi dan 2) sikap. Terdapat 16 sub konstruk dalam instrumen ini iaitu; 1) persepsi-akademik, 2) persepsi-sahsiah, 3) sikap-akademik (pelajar cemerlang), 4) (tolong-menolong dalam pelajaran), 5) sikap-sahsiah (hormat ibu bapa), 6) (bertanggungjawab) dan 7) (kejujuran). Ini ditunjukkan dalam Jadual 1. 
Jadual 1 Jumlah Item bagi setiap konstruk

\begin{tabular}{|c|l|c|c|}
\hline Bah. & Konstruk & Jumlah Item & Pernyataan Item \\
\hline 1 & Persepsi terhadap Akademik dan Sahsiah & 6 & P1 - P6 \\
\cline { 3 - 4 } & & 6 & P7 - P12 \\
\cline { 3 - 4 } & & 10 & S1.1 - S1.10 \\
\hline 2 & Sikap terhadap Akademik dan Sahsiah & 12 & S2.1 - 2.12 \\
\cline { 3 - 4 } & & & \\
\hline
\end{tabular}

Borang soal selidik yang digunakan dalam penyelidikan ini, terbahagi kepada 2 bahagian iaitu bahagian I dan II. Berikut merupakan butiran maklumat bagi setiap bahagian dalam borang soal selidik yang disediakan:

\section{Bahagian I: Persepsi}

Bahagian persepsi ini telah dibahagikan kepada 2 dimensi. Setiap dimensi dibina bagi mengukur pemboleh ubah yang telah ditentukan. 2 dimensi bagi bahagianpersepsi yang dimaksudkan ialah 1) sikap terhadap pencapaian akademik dan 2) sikap terhadap sahsiah. Terdapat 12 soalan yang dibina dalam bahagian ini. Pengukuran pemboleh ubah bagi bahagian ini adalah berdasarkan kepada skala sela kaedah likert 4 mata iaitu:

1- Sangat tidak setuju.

2- Tidak setuju.

3- Setuju.

4-Sangat setuju.

\section{Bahagian II: Sikap}

Bahagian sikap ini juga telah dibahagikan kepada 2 dimensi. Setiap dimensi dibina bagi mengukur pemboleh ubah yang telah ditentukan. 2 dimensi bagi bahagian sikap yang dimaksudkan ialah 1) sikap terhadap pencapaian akademik dan 2) sikap terhadap sahsiah. Terdapat 22 soalan yang dibina dalam bahagian ini. Pengukuran pemboleh ubah bagi bahagian ini adalah berdasarkan kepada skala sela kaedah likert 4 mata iaitu:

1- Tidak Pernah

2- Kadang-Kadang.

3- Selalu.

4- Sentiasa.

Berikut (Jadual 2) merupakan butiran maklumat mengenai kerangka pembangunan bagi instrumen yang disediakan: 
Jadual 2 Kerangka instrumen kajian

\begin{tabular}{|c|c|c|}
\hline KONSTRUK & SUB KONSTRUK & PERNYATAAN ITEM \\
\hline \multirow{12}{*}{ Persepsi } & \multirow{6}{*}{ Persepsi Akademik } & P1 Pelajaran merupakan perkara terpenting dalam kehidupan \\
\hline & & $\begin{array}{l}\text { P2 Pelajar yang rajin akan menjamin kejayaan kehidupan pada masa akan } \\
\text { datang }\end{array}$ \\
\hline & & P3 Ponteng sekolah/ kelas akan merugikan saya \\
\hline & & P4 Universiti adalah tempat orang-orang yang Berjaya \\
\hline & & P5 Ijazah merupakan bukti kejayaan dalam kehidupan \\
\hline & & P6 Saya menyambung pelajaran setelah tamat pelajaran \\
\hline & \multirow[t]{6}{*}{ Persepsi Sahsiah } & P7 Orang muda perlu menghormati orang yang lebih tua \\
\hline & & P8 Seorang anak perlu membalas jasa ibu bapanya \\
\hline & & P9 Anak yang baik sentiasa mengutamakan ibu bapanya \\
\hline & & P10 Orang yang berdisiplin adalah orang yang cemerlang \\
\hline & & P11 Semua orang suka berkawan dengan orang yang baik \\
\hline & & P12 Orang yang jujur sentiasa berasa tenang dalam kehidupan \\
\hline \multirow{22}{*}{ Sikap } & \multirow{6}{*}{$\begin{array}{l}\text { Sikap Akademik } \\
\text { (Pelajar Cemerlang) }\end{array}$} & S1.1 Sayaberasa gembira belajar di sekolah/ pusat pengajian \\
\hline & & S1.2 Saya menumpukan sepenuh perhatian ketika guru sedang mengajar \\
\hline & & S1.3 Saya akan bertanya jika saya tidak faham ketika guru sedang mengajar \\
\hline & & S1.4 Saya patuh pada arahan guru saya \\
\hline & & S1.5 Saya mengulang kaji pelajaran/membaca buku di rumah \\
\hline & & S1.6 Saya menyiapkan semua kerja sekolah/ tugasan \\
\hline & \multirow{4}{*}{$\begin{array}{l}\text { Sikap Akademik } \\
\text { (Tolong-Menolong } \\
\text { Dalam Pelajaran) }\end{array}$} & S1.7 Saya menegur rakan-rakan saya yang membuat bising di dalam kelas \\
\hline & & S1.8 Saya mengajak rakan-rakan saya untuk belajar bersama-sama \\
\hline & & S1.9 Saya berkongsi ilmu dengan rakan-rakan saya \\
\hline & & S1.10 Saya membantu rakan-rakan dalam pelajaran \\
\hline & \multirow{4}{*}{$\begin{array}{l}\text { Sikap Sahsiah } \\
\text { (Hormat Ibu Bapa) }\end{array}$} & S2.1 Saya berinteraksi dengan ibu bapa saya dengan sopan dan lemah lembut \\
\hline & & S2.2 Saya patuh pada suruhan ibu bapa saya \\
\hline & & S2.3 Saya membantu ibu bapa saya menyiapkan kerja-kerja di rumah \\
\hline & & S2.4 Saya mengutamakan keluarga berbanding orang lain \\
\hline & \multirow{4}{*}{$\begin{array}{l}\text { Sikap Sahsiah } \\
\text { (Bertanggungjawab) }\end{array}$} & S2.5 Saya memberi salam kepada semua orang \\
\hline & & S2.6 Saya membantu orang yang memerlukan \\
\hline & & S2.7 Saya menegur rakan-rakan yang membuat kesalahan \\
\hline & & S2.8 Saya menasihati orang yang lebih muda dengan perkara-perkara yang baik \\
\hline & \multirow{4}{*}{$\begin{array}{l}\text { Sikap Sahsiah } \\
\text { (Kejujuran) }\end{array}$} & S2.9 Saya melaksanakan sembahyang tanpa disuruh oleh ibu bapa saya \\
\hline & & S2.10 Saya membantu orang tanpa mengharap sebarang upah \\
\hline & & S2.11 Saya meniru di dalam peperiksaan (-) \\
\hline & & S2.12 Saya membohongi ibu bapa dan rakan-rakan saya (-) \\
\hline
\end{tabular}

\section{Kajian Rintis}

Sebelum borang soal selidik diedar kepada responden sebenar, kajian rintis perlu dilakukan bagi menguji tahap kebolehpercayaan item yang terkandung di dalamnya. Menurut Polit et. al (2001), kajian rintis adalah merujuk kepada versi kajian kecil atau percubaan yang dilakukan sebagai persediaan untuk kajian yang lebih besar atau utama. Selain sebagai kajian percubaan, kajian rintis dilakukan sebagai platform untuk menguji kebolehpercayaan sesuatu instrumen. Kebolehpercayaan merujuk kepada ketekalan satu ukuran kepada satu ukuran yang lain. Ia merupakan keputusan analisis yang diperolehi daripada sesuatu instrumen (Linn dan Miller, 2005) [14]. Ketekalan sesuatu ujian akan mencapai keputusan yang hampir sama apabila sesuatu ukuran yang boleh dipercayai digunakan pada masa yang berlainan.

Kajian rintis yang dijalankan menyediakan ruang penambahbaikan instrumen kajian yang telah dibina dengan memberi peluang kepada responden untuk mengemukakan komen serta cadangan. Kajian rintis soal selidik dilakukan bagi kajian ini ke atas sebilangan remaja yang memiliki ciri-ciri yang sama dengan responden sebenar kajian. Sebanyak 30 set borang soal selidik akan diedar bagi menjayakan projek rintis ini. Para responden dipilih secara rawak yang terdiri daripada kalangan pelajar. Data yang diperoleh daripada kajian rintis yang bakal 
dijalankan akan dimasukkan ke dalam perisisan Statistical Package for The Social Sciences (SPSS) dan seterusnya dianalisis dengan menggunakan perisian 'Winsteps'. Menerusi ujian ini, item-item yang dikenal pasti bermasalah akan digugurkan daripada instrumen sebelum instrumen tersebut diberikan ke atas responden yang sebenar bagi mendapatkan data.

\subsection{PERBINCANGAN}

Bahagian ini akan menunjukkan proses ujian kebolehpercayaan berpandukan model Rasch ke atas instrumen yang telah dibangunkan. Data daripada kajian rintis digunakan bagi menjalankan ujian kebolehpercayaan ini.

\section{Person dan Item Fit}

Nilai atau tahap kebolehpercayaan ini diperkuatkan lagi dengan kebolehpercayaan keseluruhan individu (person fit) yang sangat tinggi iaitu .95 (Azrilah et. al, 2008; Bond dan Fox, 2007; Linacre, 2005) dan menghampiri 1.0. Malah, menurut Wright \& Masters (1982), jangkaan pengulangan bagi keseluruhan item jika ditadbir oleh responden yang lain yang mempunyai ciri yang sama akan mendapat hasil yang tinggi. Indeks pengasingan pula (separation) item menunjukkan nilai yang diterima baik oleh iaitu melebihi daripada indeks 2.0 (Bond dan Fox, 2007). Dapatan diringkaskan dalam Jadual 3 yang berikut.

Jadual 3 Person fit dan item fit

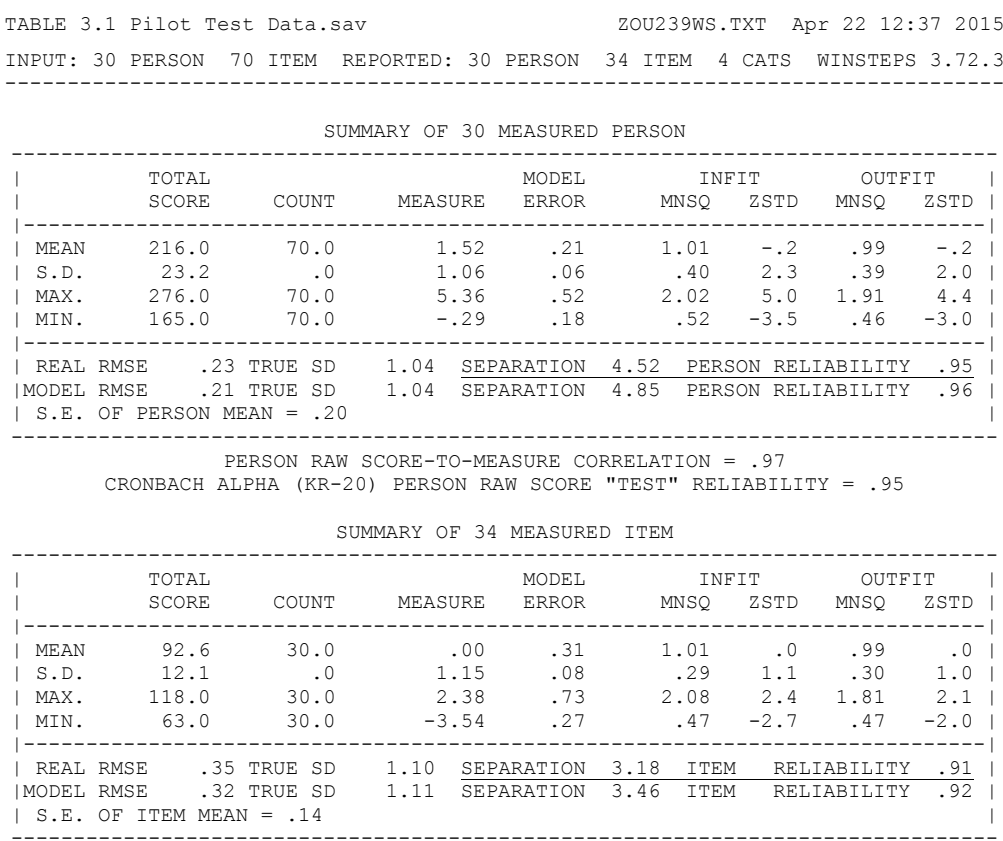

\section{Polariti Item}

Analisis polariti atau keselarian item adalah indikator yang digunakan bagi menunjukkan item bagi setiap konstruk yang digunakan bergerak dalam satu arah yang dimaksudkan dalam konstruk yang diukur. Polariti item turut berfungsi sebagai pengesahan awal bagi setiap konstruk (Bond dan Fox, 2007; Linacre, 2005). Ukuran yang mempamerkan nilai positif bagi semua item menunjukkan semua item yang ditunjukkan berfungsi ke arah yang selari untuk mengukur konstruk yang dibentuk. Sekiranya terdapat indeks yang negatif bagi sesuatu item, maka item perlu diperiksa semula sama ada perlu dibaiki atau digugurkan. Nilai point measure correlation (PT-MEASURE CORR) tidak boleh negatif (Linacre, 2005). Mana-mana nilai negatif atau di bawah 0.2 bagi konstruk perlu digugurkan kerana ia tidak mengukur apa-apa konstruk. Walau bagaimanapun, Bond \& Fox (2007) menyatakan selagi mana nilai dalam keadaan positif, ianya boleh diterima. Berdasarkan analisis, semua item bagi setiap konstruk melepasi syarat diterima iaitu berada dalam keadaan nilai positif. Ini menunjukkan semua konstruk bergerak selari bagi mengukur perkara yang ingin diukur. Ringkasan dapatan ditunjukkan dalam Jadual 4 dan Jadual 5. 
Jadual 4 Polariti Item bagi konstruk persepsi

TABLE 26.1 Pilot Test Data.sav $\begin{aligned} & \text { ZOU765WS.TXT Apr } 22 \text { 12:46 } 2015 \\ & \text { TNPUT }\end{aligned}$

PERSON: REAL SEP.: 1.59 REL.: .72 ‥ ITEM: REAL SEP.: 3.38 REL.: .92

ITEM STATISTICS: CORRELATION ORDER

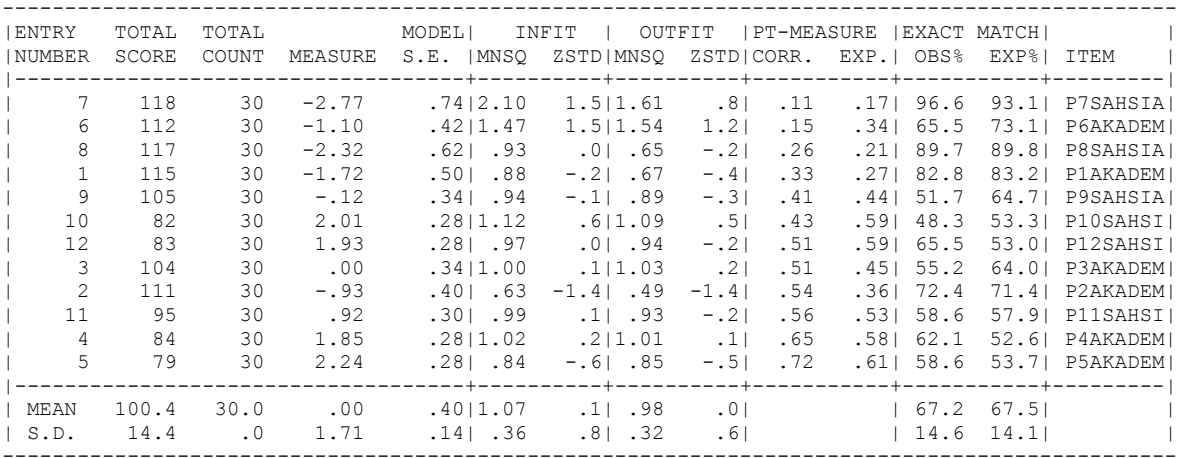

Jadual 5 Polariti Item bagi konstruk sikap

TABLE 26.1 Pilot Test Data.sav ZOU268WS.TXT Apr 22 12:47 2015 INPUT: 30 PERSON 22 ITEM REPORTED: 30 PERSON 22 ITEM 4 CATS WINSTEPS 3.72 .3

PERSON: REAL SEP.: 2.96 REL.: .90 ... ITEM: REAL SEP.: 2.45 REL.: .86

ITEM STATISTICS: CORRELATION ORDER

\begin{tabular}{|c|c|c|c|c|c|c|c|c|c|c|c|c|}
\hline $\begin{array}{l}\text { ENTRY } \\
\text { NUMBER }\end{array}$ & $\begin{array}{l}\text { TOTAL } \\
\text { SCORE }\end{array}$ & $\begin{array}{l}\text { TOTAL } \\
\text { COUNT }\end{array}$ & MEASURE & $\begin{array}{l}\text { MODEL | I } \\
\text { S.E. |MNSQ }\end{array}$ & $\begin{array}{l}\text { IT | } \\
\text { ZSTD|I }\end{array}$ & $\begin{array}{r}\text { OU' } \\
\text { MNSQ }\end{array}$ & $\begin{array}{l}\text { FIT } \\
\text { ZSTD }\end{array}$ & $\begin{array}{l}\text { | PT-MER } \\
\text { | CORR. }\end{array}$ & $\begin{array}{l}\text { SURE । } \\
\text { EXP. | }\end{array}$ & $\begin{array}{l}\text { EXACT } \\
\text { | OBS\% }\end{array}$ & $\begin{array}{r}\text { MATCH } \\
\text { EXP }\end{array}$ & ITEM \\
\hline 21 & 99 & 30 & -1.15 & $.32 \mid 1.09$ & .511. & 1.12 & .5 & .33 & .521 & | 50.0 & $61.7 \mid$ & S2.11 \\
\hline 19 & 98 & 30 & -1.04 & $.32 \mid 2.03$ & 3.412 & 2.00 & 2.6 & .33 & .531 & | 53.3 & 61.11 & S2. 9 \\
\hline 22 & 97 & 30 & -.94 & .321 .62 & $-1.8 \mid$ & .69 & -1.0 & .43 & .541 & 70.0 & 60.51 & $\mathrm{~S} 2.12$ \\
\hline 12 & 94 & 30 & -.64 & $.311 \quad .97$ & -.11 & 1.05 & .3 & .49 & .551 & | 53.3 & 59.71 & $\mathrm{~S} 2.2$ \\
\hline 11 & 99 & 30 & -1.15 & .321 .65 & $-1.6 \mid$ & .83 & -.4 & .51 & .521 & 70.0 & 61.71 & S2.1SIKA \\
\hline 1 & 90 & 30 & -.25 & $.31 \mid .96$ & -.11 & .97 & .0 & .53 & .571 & | 70.0 & 59.71 & S1.1SIKA \\
\hline 20 & 97 & 30 & -.94 & $.32 \mid 1.24$ & 1.011 & 1.11 & .5 & .54 & .541 & 70.0 & 60.51 & $\mathrm{~S} 2.10$ \\
\hline 15 & 79 & 30 & .83 & $.32 \mid 1.45$ & 1.71 & 1.33 & 1.2 & .57 & .601 & | 46.7 & 61.01 & S2. 5 \\
\hline 9 & 89 & 30 & -.15 & $.31 \mid .64$ & $-1.7 \mid$ & .64 & -1.5 & .58 & .571 & | 76.7 & 59.61 & S1. 9 \\
\hline 8 & 77 & 30 & 1.04 & $.32 \mid 1.21$ & .91 & 1.20 & .8 & .58 & .601 & | 53.3 & 62.21 & $\mathrm{~S} 1.8$ \\
\hline 7 & 68 & 30 & 2.05 & $.35 \mid 1.27$ & 1.01 & 1.27 & 1.0 & .58 & .591 & | 63.3 & 67.41 & S1.7 \\
\hline 2 & 79 & 30 & .83 & .321 .90 & -.31 & .85 & -.5 & .58 & .601 & | 66.7 & 61.01 & $\mathrm{~S} 1.2$ \\
\hline 6 & 86 & 30 & .14 & $.31 \mid .98$ & .01 & .95 & -.1 & .58 & .581 & | 53.3 & 59.41 & S1. 6 \\
\hline 16 & 78 & 30 & .94 & .321 .87 & -.51 & .90 & -.3 & .59 & .601 & 70.0 & 61.21 & S2. 6 \\
\hline 5 & 80 & 30 & .73 & $.32 \mid 1.06$ & .31 & 1.04 & .2 & .60 & .591 & | 60.0 & 60.81 & S1. 5 \\
\hline 13 & 83 & 30 & .43 & $.31 \mid 1.07$ & .41 & .99 & .0 & .62 & .591 & | 63.3 & 59.11 & $\mathrm{~S} 2.3$ \\
\hline 10 & 88 & 30 & -.05 & $.31 \mid .68$ & -1.4 & .66 & -1.4 & .64 & .581 & 76.7 & 59.61 & S1.10 \\
\hline 3 & 80 & 30 & .73 & $.32 \mid 1.10$ & .51 & 1.04 & .2 & .64 & .591 & | 60.0 & 60.81 & $\mathrm{~S} 1.3$ \\
\hline 14 & 102 & 30 & -1.47 & .331 .87 & -.51 & .80 & -.4 & .65 & .501 & | 63.3 & 63.11 & S2. 4 \\
\hline 4 & 91 & 30 & -.35 & $.31 \mid .75$ & $-1.1 \mid$ & .71 & -1.1 & .69 & .561 & | 70.0 & 59.61 & $\mathrm{~S} 1.4$ \\
\hline 18 & 90 & 30 & -.25 & $.31 \mid .78$ & -.91 & .73 & -1.0 & .70 & .571 & | 76.7 & 59.71 & $\mathrm{~S} 2.8$ \\
\hline 17 & 81 & 30 & .63 & .321 .80 & -.81 & .73 & -1.0 & .77 & .591 & 66.7 & 60.51 & S2.7 \\
\hline 17 & 87.5 & 30.0 & .00 & .3211 .00 & -.11 & .98 & -.1 & & । & $\begin{array}{l}\mid \\
\mid\end{array} 63.8$ & 60.91 & \\
\hline & 8.9 & .0 & .89 & $.01 \mid .31$ & 1.21 & .30 & .9 & & i & 8.8 & 1.71 & \\
\hline
\end{tabular}

\section{Dimensionality}

Analisis prinsipal komponen digunakan bagi menentukan sesuatu item itu bersifat unidimensi atau tidak. Item yang bersifat unidemensi adalah item yang hanya mengukur satu keupayaan yang tunggal (Bond dan Fox, 2007; Linacre, 2005). Menurut Linacre (2005), tahap Variance explained by measure perlu melebihi $40 \%$ untuk memastikan dimensionality item-item dalam sesuatu konstruk berada dalam keadaan yang baik. 
Jadual 6 Dimensionality Item bagi konstruk persepsi

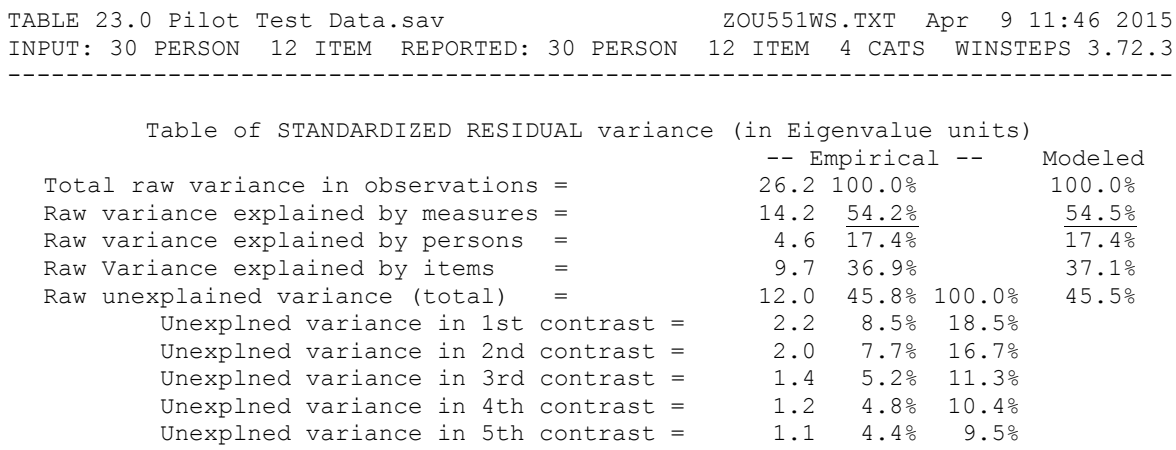

Jadual 7 Dimensionality Item bagi konstruk sikap

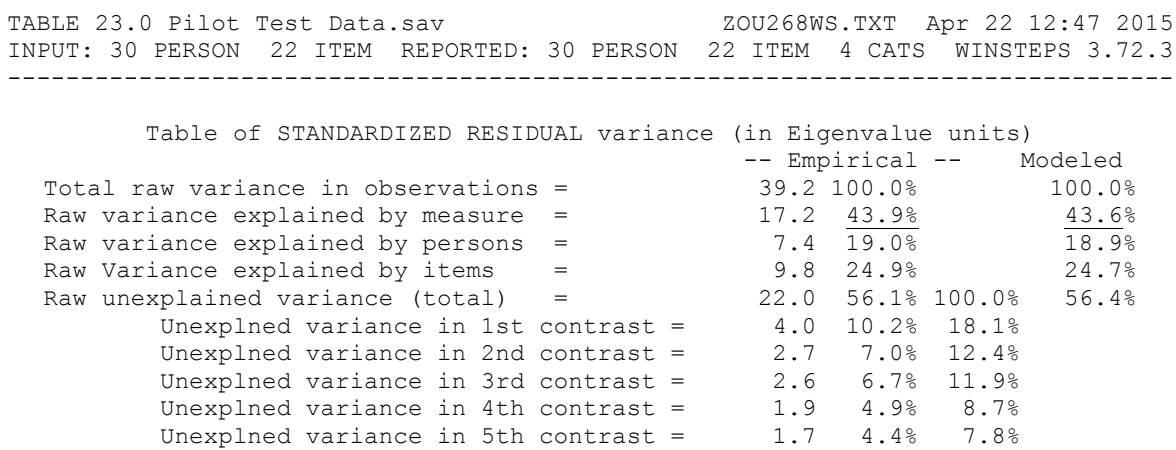

Berdasarkan ujian analisis menunjukkan nilai dimensionality bagi konstruk persepsi dan sikap melepasi tahap yang ditetapkan 40\%. Ini menunjukkan dalam konstruk faktor terdapat item yang yang bersifat multidimensi (item yang mengukur dimensi secara luas). Ini ditunjukkan dalam Jadual 6 dan Jadual 7. Item-item ini boleh dianggap bermasalah. Bagi mengenal pasti item-item yang bermasalah ini adalah menerusi ujian kesepadanan item (item infit).

\section{Kesepadanan Item (infit)}

Analisis menggunakan model Rasch mampu menganggarkan darjah kesepadanan dan kesesuaian item yang mengukur sesuatu pemboleh ubah yang terpendam. Kesepadanan dan kesesuaian sesuatu item mampu mempengaruhi tahap kebolehpercayaan sesuatu instrumen. Ujian kesepadanan item ini bertujuan untuk mengesahkan kesepadanan setiap item. Menurut Bond and Fox (2007), item yang mempunyai nilai infit atau outfit MNSQ melebihi 1.40 logit menunjukkan logit tidak homogen dengan item yang lain dalam satu pengukuran skala. Manakala nilai infit atau outfit MNSQ kurang daripada 0.6 logit menunjukkan berlaku pertindihan antara sesuatuitem dengan yang item yang lain.Itemitem yang berada di luar julat tersebut $(0.6<\mathrm{x}<0.14)$ perlu digugurkan bagi meningkatkan lagi kualiti sesuatu instrumen. Analisis ditunjukkan dalam Jadual 8 dan Jadual 9.

Jadual 8 Nilai In fit Item bagi konstruk persepsi

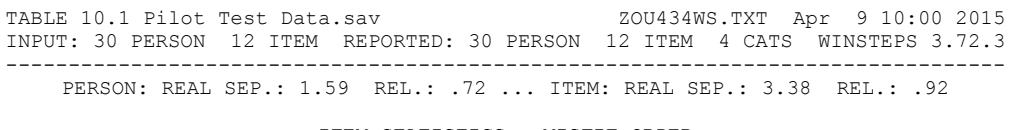

ITEM STATISTICS: MISFIT ORDER

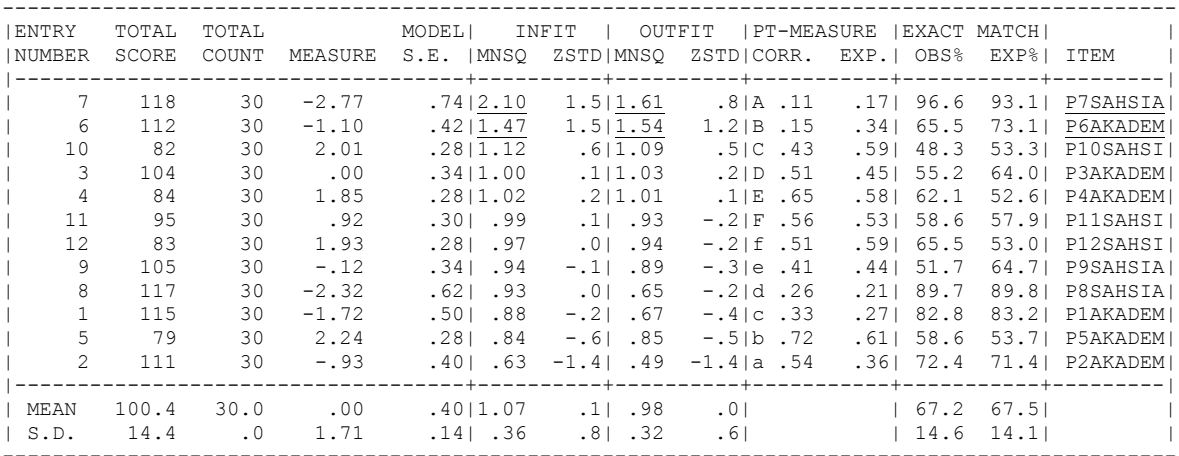


Jadual 9 Nilai In fit item bagi konstruk sikap

TABLE 10.1 Pilot Test Data.sav
INPUT: 30 PERSON 22 ITEM REPORTED: 30 PERSON 22 ITEM 4 CATS WINSTEPS 3.72 .3

PERSON: REAL SEP.: 2.96 REL.: .90 ‥ ITEM: REAL SEP.: 2.45 REL.: .86

ITEM STATISTICS: MISFIT ORDER

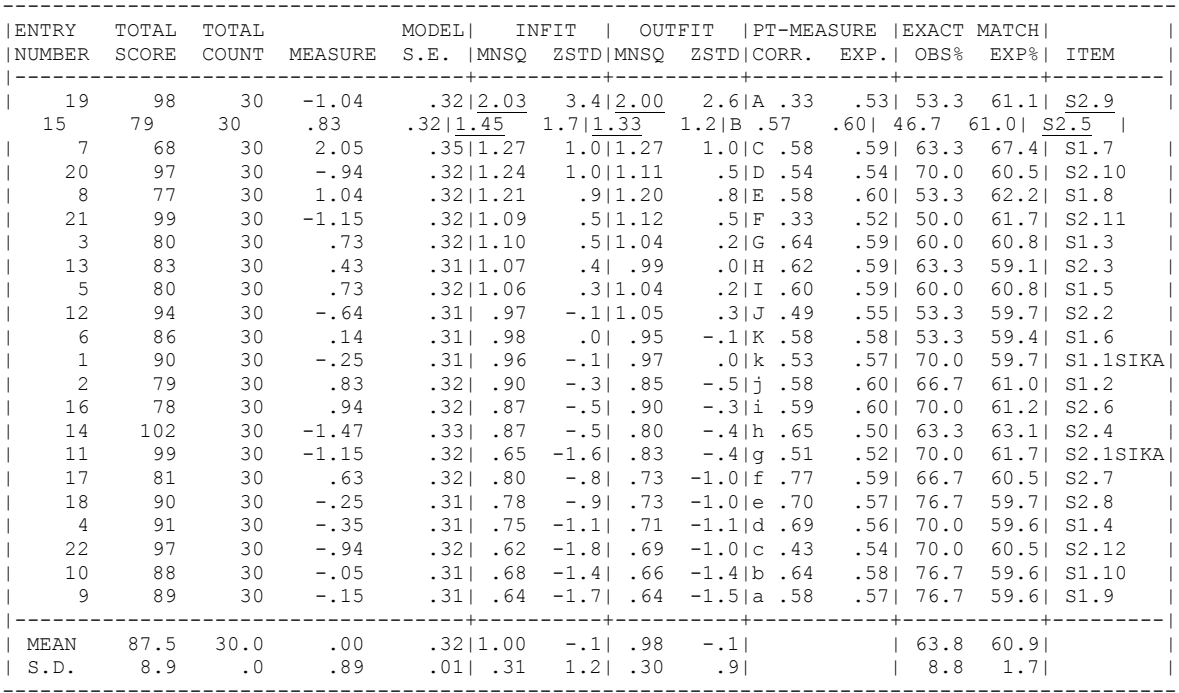

Berdasarkan ujian kesepadanan item yang dijalankan, terdapat 2 item bgi persepsi dan 2 item bagi sikap yang berada diluar julat yang dibenarkan $(0.6<x<0.14)$. Item-item ini dikenali sebagai item-item yang misfit atau item-item yang bermasalah. Item-item yang berada diluar julat tersebut perlu digugurkan bagi meningkatkan dimensionality konstruk lantas meningkatkan kebolehpercayaan instrumen ini.

\section{Dimensionality Selepas Mengeluarkan 4 Item Bermasalah (misfit)}

Setelah dikenal pasti item-item yang bermasalah (misfit), pengkaji mengambil keputusan untuk mengeluarkan item-item yang berkenaan. Ujian dimensionality telah dijalankan semula bagi memastikan peningkatan kualiti konstruk setelah mengeluarkan item-item yang bermasalah. Menurut Linacre (2005) variance explained by measure perlu melebihi $40 \%$ untuk memastikan dimensionality item-item dalam sesuatu konstruk dalam keadaan yang baik. Berdasarkan ujian dimensionality kali kedua ini, didapati telah berlaku peningkatan nilai variance explained by measure dalam kedua-dua konstruk. Hasil analisis ditunjukkan dalam Jadual 10 dan Jadual 11.

Jadual 10 Dimensionality Item bagi konstruk persepsi selepas membuang 2 item misfit

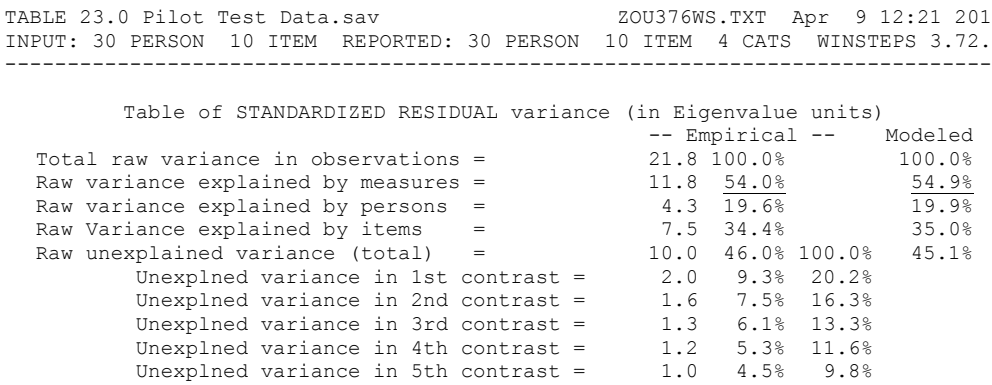


Jadual 11 Dimensionality Item bagi konstruk sikap selepas membuang 2 item misfit

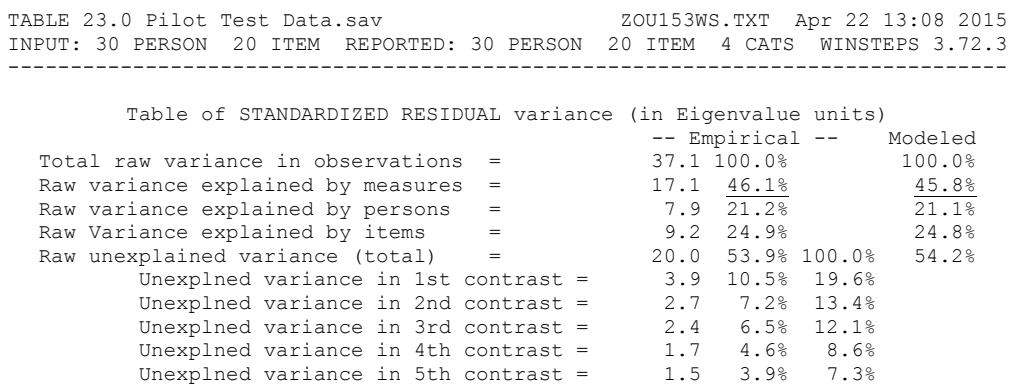

Instrumen Kajian Selepas Proses Kesahan dan Kebolehpercayaan

Setelah instrumen menjalani ujian kesahan dan kebolehpercayaan menerusi kaedah Rasch Model, pengkaji telah menggugurkan 4 daripada 34 item. Item-item ini tidak sepadanan dengan item-item yang lain dan boleh dianggap bermasalah. Berikut merupakan maklumat item-item yang telah digugurkan dalam setiap konstruk (Jadual 12):

Jadual 12 Maklumat Item yang digugurkan bagi setiap konstruk

\begin{tabular}{|c|c|c|c|c|}
\hline Konstruk & $\begin{array}{l}\text { Jumlah Item } \\
\text { Sebelum } \\
\text { Digugurkan }\end{array}$ & $\begin{array}{r}\text { Jumlah Item yang } \\
\text { Digugurkan }\end{array}$ & Pernyataan Item yang Digugurkan & $\begin{array}{c}\text { Jumlah Item Selepas } \\
\text { Digugurkan }\end{array}$ \\
\hline \multirow{2}{*}{$\begin{array}{c}\text { Persepsi terhadap } \\
\text { Akademik dan } \\
\text { Sahsiah }\end{array}$} & 6 & $\begin{array}{c}1 \\
(\mathrm{P} 6)\end{array}$ & $\begin{array}{l}\text { Saya menyambung pelajaran setelah } \\
\text { tamat persekolahan }\end{array}$ & 5 \\
\hline & 6 & $\begin{array}{c}1 \\
(\mathrm{P} 7)\end{array}$ & $\begin{array}{l}\text { Orang muda perlu menghormati orang } \\
\text { tua }\end{array}$ & 5 \\
\hline \multirow{2}{*}{$\begin{array}{c}\text { Sikap Akademik dan } \\
\text { Sahsiah }\end{array}$} & 10 & - & - & 10 \\
\hline & 12 & $\begin{array}{c}2 \\
(\mathrm{~S} 2.5 \& 2.9)\end{array}$ & $\begin{array}{l}\text { 1) Saya memberi salam kepada semua } \\
\text { orang } \\
\text { 2) Saya melaksanakan sembahyang tanpa } \\
\text { disuruh oleh ibu bapa }\end{array}$ & 10 \\
\hline
\end{tabular}

\subsection{RUMUSAN}

Hasil ujian kebolehpercayaan bagi instrumen mencatatkan nilai kebolehpercayaan .95 bagi individu dan .91 bagi item menunjukkan instrumen mempunyai tahap kebolehpercayaan yang tinggi. Selain itu, pengujian dimensionality mendapati nilai variance explained by measure bagi kedua-dua konstruk telah mencatatkan lebih daripada 40\%. Hasil daripada ujian item infit pula mendapati bahawa 2 daripada 12 item persepsi dan 2 daripada 12 item sikap misfit. Oleh itu, sebanyak 4 item daripada jumlah keseluruhan 34 item telah digugurkan daripada instrumen. Ujian dimensionality telah dijalankan semula bagi memastikan peningkatan kualiti konstruk setelah membuang itemitem yang bermasalah. Berdasarkan ujian dimensionality kali kedua, didapati telah berlaku peningkatan nilai variance explained by measure dalam kedua-dua konstruk yang membolehkan setiap item dalam setiap konstruk bersifat unidimensi.

\section{Rujukan}

Adibah Abdul Latif (2013). Pembangunan Instrumen Penilaian Akhlak Pelajar di Institusi Pengajian Tinggi Awam. Tesis Doktor Falsafah UTM Skudai.

Asmawati Desa (2004). Psikologi untuk Golongan Profesional. Kuala Lumpur : McGraw-Hill.

Atkinson, r. L.,Atkinson. R. C. dan Hilgard, E. R. (1983). Introduction to Psychology. $8^{\text {th }}$ edition. Harcourt Brace Jovanovich

Azhar Hj. Wahid dan Zawawi Jahya. (2009). Pendidikan Pembangunan Modal Insan. Tanjong Malim: Penerbit UPSI.

Azrilah, A.A., Azlinah, M., Noor Habibah, A., Hamzah, A. G., Sohaimi, Z. \& Saidfudin, M. (2008). Application of Rasch Model in Validating the Construct of Measurement Instrument. International Journal of Education and Information Technologies, 2, 105-112.

Bechtel, G. G. (1985). Generalizing The Rasch Model For Consumer Rating Scales. Marketing Science, 4(1), 62-73.

Bezruczko, N. (2005). Rasch Measurement In Health Sciences. Maple Grove, MN: Jam Press.

Bond, T. \& Fox, C. (2007). Applying The Rasch Model: Fundamental Measurement In The Human Sciences (2nd). Mahwah, NJ: LEA.

Breckler, S. J. (1984). Empirical Validation Of Affect, Behavior, And Cognition As Distinct Components Of Attitude. Journal of Personality and Social Psychology. 47(6), 1191-1205.

Ciccarelli, S. K. (2006). Psychology. New Jersey: Pearson Prentice Hall.

De Cecco, J. P., and Crawford, W. R. (1974). The Psychology of Learning and Instruction. Educational Psychology. New Jersey: Prentice-Hall. 
Faizah Abd. Ghani, Adibah Abdul Latif, Azian Abd Aziz dan Aqeel Khan (2015). Validity and Reliability Analysis of the 'SayangKU' (MyLove) in Intervention for Addressing Adolescents Involved in Free Sex. Journal of Religion and Health, 54 (4), 1375-1386.

Garrisson, K. C., Kingston, A. J., McDonald A. S., (1964). Educational Psychology. New York: Appleton Century Crofts Division of Meredith Publishing Company. Kamus Dewan Edisi Keempat (2005). Kuala Lumpur: Dewan Bahasa dan Pustaka.

Linacre, J. M. (2005). WINSTEPS: Multiple-Choice, Rating Scale, And Partial Credit Rasch Analysis [computer software]. Chicago: MESA.

Linn, R. L. and Miller, M. D. (2005). Measurement And Assessment In Teaching, 9th Edition. Upper Saddle. River, NJ: Prentice Hall.

Miftah Thoha. (2003). Kepemimpinan Dalam Manajemen. Jakarta : PT. Raja Grafindo Persada.

Mohd Aziz Shah Mohd Arip dan Nazariah Abdul Samad (2008). Fasilitator Efektif \& Dinamik. Kuala Lumpur: PTS Professional Publication.

Mohd. Azhar Abdul Hamid (2007). Meningkatkan Daya Fikir. Selangor: PTS Publications \& Distributors Sdn. Bhd.

Muhd Sulaiman Yasin. (1992). Akhlak dan Tasauf. Bangi: Yayasan Salman.

Petty, R. E., \& Cacioppo, J. T. (1986). Communication and Persuasion: Central and Peripheral Routes to Attitude Change. New York: Springer-Verlag.

Polit, D.F., Beck, C.T. \& Hungler, B. P. (2001). Essentials of Nursing Research: Methods, Appraised and Utilization, (5th. ed.), Philadelphia: Lippincott William \& Walkins.

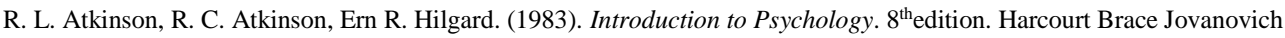

Rozmi Ismail. (2011). Psikologi Sosial. Selangor: Penerbit Universiti Kebangsaan.

Smith, Louis. M., and Hudgins, Bryce. B. (1964). Educational Psychology. An Application of Social and Behavioral Theory. New York: Alfred A. Knopt.

Sugihartono. (2007). Psikologi Pendidikan. Yogyakarta: UNY Press.

Sunaryo (2004). Psikologi Untuk Keperawatan. Jakarta: EGC.

Wan Azmi Ramli. (1986). Ranjau Hidup: Keluarga, Aspek Psikologi dan Sosial. Kuala Lumpur: Utusan Publications \& Distributiors.

Wan Suryati Wan Ahmad. (2008). Pengaruh Sikap dan Demografi Ke Atas Produktiviti Kerja Pensyarah Muslim: Kajian di Universiti Malaya. Jurnal Syariah, 16.2, ,321-344. Universiti Malaya.

Wright, B. D. (1977). Solving Measurement Problems With The Rasch Model. Journal of Educational Measurement, 14 (2), 97-116.

Wright, B. D. and Masters, G. N. (1982). Rating Scale Analysis. Chicago: MESA Press.

Yelon, S. L., Weinstein, G. W., and Weener, P. A., (1977). Teacher's World. Psychology in the Classroom. Tokyo: Mc Graw-Hill, Inc. 